Closer relationships of $P$. uliginosa with dwarf mountain pine mirrors also reported crossability. Peat-bog pine share some traits with Scots pine due to introgression but could lost crossability due to isolation.

Based on these data and earlier studies, close phylogenetic relationship between $P$. uliginosa and $P$. mugo complex is suggested. This experiment is based on limited material and includes only one way of pollination. Therefore, in context of hypothesized P. uliginosa hybrid derivation, the obtained results unable to infer definitely about putative parental species. Reliable experiments should be founded on a more detailed material, representing more comprehensively examined populations of different species and conducted for several years to exclude influence of biotic and abiotic factors.

\section{References}

Boratyński, A., K. Boratyńska, A. LeWANDOWSKI, Z. GolA̧B and P. KosiŃsKI (2003): Evidence of the possibility of natural reciprocal crosses between Pinus sylvestris and Pinus uliginosa based on the phenology of reproductive organs. Flora 198: 377-388.

BusinskÝ, R. (1999): Taxonomic essay in the Pinus mugo complex and its hybrid population (in Czech). Acta Pruhoniciana 68: 123-143.

Christensen, K. I. (1987): Taxonomic revision of the Pinus mugo complex and $P$. $\mathrm{x}$ rhaetica $(P$. mugo $\mathrm{x}$ sylvestris) (Pinaceae). Nord. J. Bot. 7: 383-408.

DANIELEWICZ, W. and J. ZIELIŃSKI (2000): Ochrona sosny blotnej Pinus uliginosa A. Neumann na terenie Borów Dolnośląskich. Przegl. Przyr. 9: 113-124.

KORMUTAK, A. and M. LANAKOWA (1988): Biochemistry of reproductive organs and hybridological relationships of selected pine species (Pinus sp.). Acta Dendrob. 7-103.

Krzakowa, M., B. NaganowsKa and M. A. Bobowicz (1984): Investigations on taxonomic status of Pinus uliginosa Neumann. Bull. Soc. Pol. Acad. Sci. 24: 87-95.

Lewandowski, A., A. Boratyński and L. Mejnartowicz (2000): Allozyme investigations on the genetic differentiation between closely related pines - Pinus sylvestris, P. mugo, P. uncinata and P. uliginosa (Pinaceae). Pl. Syst. Evol. 221: 15-24.
Lewandowski, A., J. Samoćko, K. Boratyńska and A. BoRATYŃSKI (2002): Genetic differences between two Polish populations of Pinus uliginosa, compared to P. sylvestris and P. mugo. Dendrobiology 48: 51-57.

MarCET, E. (1967): Über den Nachweis spontaner Hybriden von Pinus mugo Turra und Pinus sylvestris auf Grund von Nedelmerkmalen. Ber. Schweiz. Bot. Ges. 77: 314-361.

Moulalis, D., C. Bassiotis and D. Mitsopoulos (1976): Controlled pollinations among Pine species in Grece. Silvae Genet. 25: 95-107.

Muir, G., C. C. Fleming and C. Schlatterer (2000): Species status of hybridizing oaks. Nature 405: 1016.

PRUs-Glowacki, W. and J. SzweYKowsKI (1980): Serological characteristics of some putative hybrid individuals from a $P$. sylvestris x $P$. mugo swarm population. Acta Soc. Bot. Pol. 49: 127-142.

Prus-Glowacki, W. and J. Szweykowski, 1983: Studies on isoenzyme variability in populations of Pinus sylvestris L., Pinus mugo Turra, Pinus uliginosa Neumann and individuals from a hybrid swarm population. Bull. Sci. Amis. Poznać. 22: 107-122.

Siedlewska, A. and W. Prus-Glowacki (1995): Genetic structure and taxonomic position of Pinus uliginosa Neumann population from Wielkie Torfowisko Batorowskie in Stolowe Mts. (Locus classicus). Acta Soc. Bot. Pol. 64: 1-8.

Staszkiewicz, J. and M. Tyszkiewicz (1969): Naturalne mieszańce Pinus mugo Turra x Pinus sylvestris L. w Kotlinie Nowotarskiej. Fragm. Flor. Geobot. 15: 187-212.

Staszkiewicz, J. (1993): Variability of Pinus mugo x $P$. sylvestris (Pinaceae) hybrid swarm in the Tisovnica nature reserve (Slovakia). Polish Bot. Stud. 5: 33-41.

WACHowiaK, W., A. BA̧CZKIEWICZ, K. CELIŃSKI and W. PRUSGLOWACKI (2004): Species-specific chloroplast DNA polymorphism in the trnV-rbcL region in Pinus sylvestris and Pinus mugo. Dendrobiology 51: 67-72.

WACHOWIAK, W., K. Celiński and W. Prus-Glowacki (2005): Evidence of natural reciprocal hybridization between Pinus uliginosa and $P$. sylvestris in sympatric population of the species. Flora 200: 563-568.

\title{
DNA From Ancient Cedar Wood From King Midas' Tomb, Turkey, and Al-Aksa Mosque, Israel
}

\author{
By S. O. Rogers ${ }^{1), 2), *)}$ and Z. KAYA ${ }^{1), 3)}$
}

(Received 22 $2^{\text {th }}$ July 2005)

\footnotetext{
1) State University of New York, College of Environmental Science and Forestry, Syracuse, NY, USA.

${ }^{2}$ ) Current Address: Department of Biological Sciences, Bowling Green State University, Bowling Green, OH, USA.

$\left.{ }^{3}\right)$ Current Address: Department of Biological Sciences, Middle East Technical University, 06531 Ankara, Turkey.

*) Corresponding author: SOR; phone: 419-372-2333; fax: 419372-2024; E-mail address: srogers@bgnet.bgsu.edu
}

\begin{abstract}
Ancient Taurus cedar (Cedrus libani A. Rich) wood samples from the Tumulus of King Midas at the Gordion archaeological site (about 2700 years old), near Ankara, Turkey, and from the Al-Aksa Mosque (about 1500 to 1900 years old), Jerusalem, Israel, were characterized by studying the sequences of ribosomal DNA (rDNA) internal transcribed spacers (ITS1 and ITS2). After
\end{abstract}


extraction of the DNA, the ITS regions were amplified utilizing the polymerase chain reaction, followed by sequencing, BLAST searches for similar sequences, and phylogenetic analyses. Fifty-six sequences were obtained. In BLAST searches of existing sequence databases, most were closest to those from humans and fungi. However, two sequences exhibited similarities with conifer ITS sequences. One was an ITS1 region from the Gordion wood specimen, and the other one was an ITS2 region from the Al-Aksa wood specimen. Phylogenetic analyses indicated that both were closest to Taurus cedar (C. libani, also known as Lebanon cedar) ITS sequences from three recent samples of Taurus cedar from two sites in Turkey. However, they exhibited many differences from the recent $C$. libani rDNA ITS sequences from Turkey, probably due to degradation of the DNA in the ancient samples. The implications of the results on future studies are discussed.

Key words: Ancient DNA, Midas, Gordion, Cedrus libani, wood.

\section{Introduction}

The major vegetation type in central Anatolia below $700 \mathrm{~m}$ of elevation is typical steppe. For the areas above $700 \mathrm{~m}$ of elevation, and usually at the edges of steppe vegetation, scattered trees are common in a steppe-forest formation that can be fairly dense in higher elevations. Millennia of human influence on the landscape make it hard to imagine how the natural vegetation of central Anatolia once appeared. But pollen and charcoal studies in archaeological sites in central Turkey such as the ancient Gordion city site suggest that the major vegetation of the past consisted of juniper, pine and oak species. The ancient Gordion city was the capital of the Phyrigian Civilization and it is one of the few excavated urban sites in central Turkey that date to the second millennium B.C., and was occupied continuously for several thousand years. Environmental deterioration, caused by deforestation and grazing at this site and other similar archaeological sites in the vicinity, has been documented, and seems to be a relatively recent phenomenon (MILlER, 1998; MilleR, 1999).

The discovery of rare wood in the Midas (the Phrygian King) Tumulus indicates that there might have been continuous forest from south to north including the Gordion site. For instance, juniper (Juniperus spp.), pine (Pinus nigra pallasiana), and Taurus cedar (Cedrus libani) timbers are present in the Midas Tumulus. The presence of Taurus cedar wood is especially interesting since the closest natural cedar forest, that is in Afyon province today, is about $100 \mathrm{~km}$ south of Gordion. The closest natural occurrence of Taurus cedar forest to the northeast (Niksar and Erbaa towns of Tokat Province) is about $500 \mathrm{~km}$ from Gordion (BoydAK, 2003; Figure 1). Also, present in the Tumulus is furniture made from boxwood (Buxus sempervirens). Again, the closest boxwood stands are located in the Black Sea forests that are about $125 \mathrm{~km}$ north of the Gordion site. These findings suggest that Taurus cedar timbers either were carried from long distances for wealthy and powerful persons, such as in the case of the King Midas Tumulus (MilleR, 1999), or the cedar forests once were continuous from Afyon in the south, to Niksar (Tokat Province) in the north, where the natural cedar stands can be still seen today (AYTUG, 1988; BoYDAK, 2003). Similarly, C. libani in Israel and surrounding countries consists of very limited refugia, presumably being remnants of more extensive forests. In either case, considering the current distribution of Taurus cedar, as well as other tree species that coexist with Taurus cedar in the Middle East, large portions of the forest genetic resources may have been lost permanently. It is important to establish the ancient distribution of $C$. libani in the Middle East. It will be of interest to identify the alleles that potentially have been responsible for adaptation of Taurus cedar to changing environments and wood production in the past several thousand years.

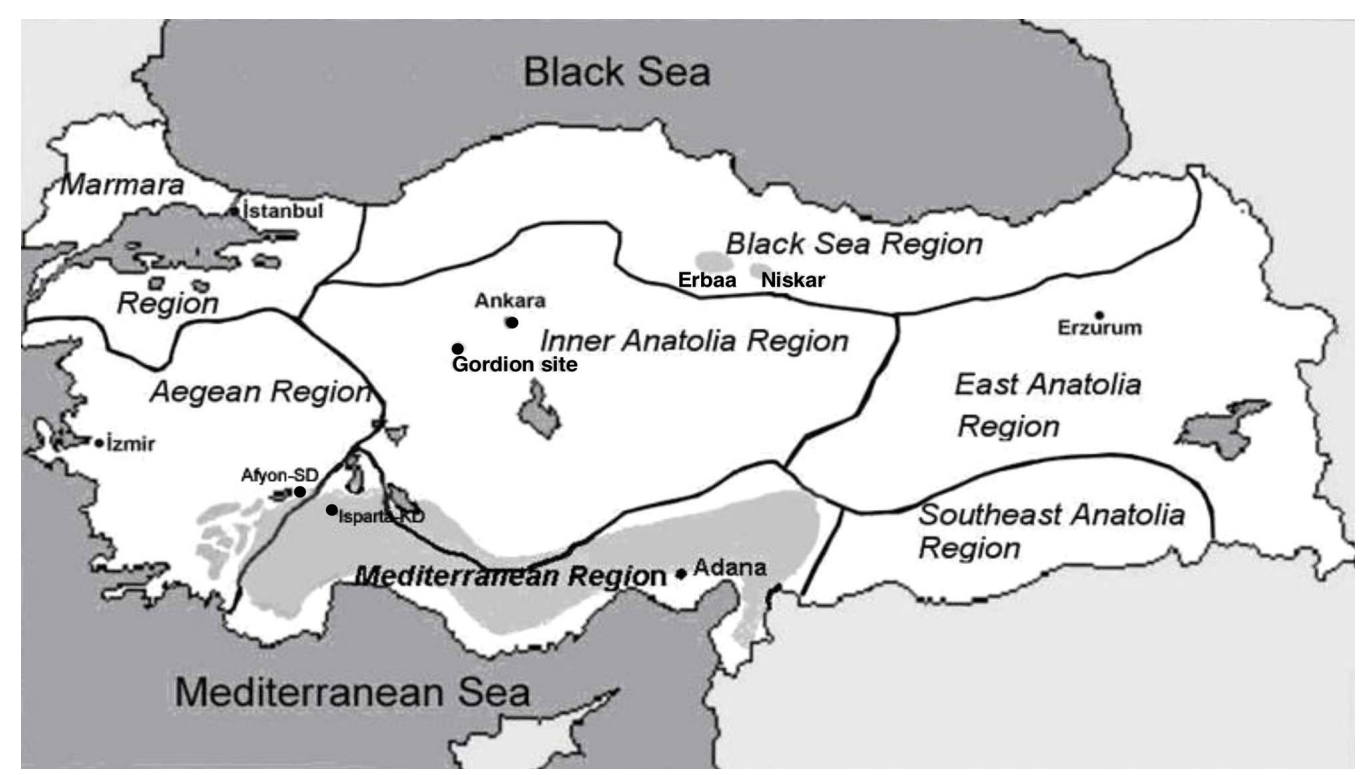

Figure 1. - Map of the natural range of C. libani in Turkey (shaded areas) and the location of the Gordion archeological site. Afyon-SD and Isparta-KD on the map indicate the locations of the recent C. libani samples of Afyon-Sultandag (ZK AS 31704 4) and Isparta-Kapidag (ZK IK 317044 and ZK IK 31704 12), respectively. 
Previous DNA studies (KAYIHAN, 2000) of Taurus cedar indicated that there remains a large amount of genetic diversity in the studied populations although the magnitude of diversity is lower than some other conifers occurring in the same geographic regions (KANDEDMIR et al., 2004; IÇGEN, 2003). It is possible that Taurus cedar genetic resources in the Mediterranean regions have diminished over the centuries due to human activities. Ancient preserved specimens represent a resource of potentially useful alleles that have become extinct. The genetic composition of animal and plant species can be deduced from their fossils (bones, wood, seeds, etc.) and materials as old as tens of thousands of years old, as well as living tissues, such as leaves, buds, embryos, and other tissues using molecular methods developed for ancient specimens (CANO and BORUCKI, 1995; GUGERLI et al., 2005; Hofreiter et al., 2001; MA et al., 2000; РÄÄBO 1985, 1993; PARduCCI and Petit, 2004; Rogers, 1994; RoGERS and BENDICH, 1985, 1988, 1994; RoGERS et al., 1989; SAVOLINEN et al., 1995). The great majority of ancient DNA (aDNA) studies have been with animal tissues, while molecular studies of wood are limited to a few reports (DEGUILloux et al., 2002; Hofreiter et al., 2001; KIM et al., 2004; PARDUCCI and PETIT, 2004; TANI et al., 2003). A study of intraspecific aDNA from fossils and archaeological materials (e.g., Taurus cedar wood from the Midas Tumulus and other sites) could provide linking information between palaeoecology, population genetics, and phylogeography of species that should improve our knowledge of past evolutionary processes (GUGERLI et al., 2005; TANI et al., 2003).

The wood of Taurus cedar in the Midas Tumulus was preserved to an extent that it could be identified by AYTUG (1988). Thus, it is possible to investigate the genetic structure of the buried wood materials and assess genetic differentiation between the buried materials representing the past population and nearest present population of the species. With this study, the groundwork is established to sequence DNA from ancient $C$. libani wood specimens. The specific objectives of the current study were as follows: (1) to optimize the DNA extraction procedure from ancient Taurus cedar wood specimens from the King Midas Tumulus in Gordion that are about 2700 years old and from specimens, and from the Al-Aksa Mosque (removed and stored during renovations from 1969-70 repair work) that are 1500 to 1900 years old; and (2) to characterize the DNA from ancient Taurus cedar wood specimens using molecular methods.

\section{Materials and Methods}

\section{Specimens}

Two ancient C. libani wood specimens were examined in this study. One was from the Anatolian Civilization Museum, Ankara, Turkey (provided by Mr. HikmeT Denizli and Mr. Mehmet AkAlin, Anatolian Civilization Museum, Ankara, Turkey). Originally, it was part of the King Midas Tumulus $100 \mathrm{~km}$ west of Ankara (Figures 1 and 2) and was estimated to be approximately 2700 years old (FILLEY et al., 2001). The other wood specimen was from Al-Aksa Mosque, Jerusalem, Israel. It was sampled from a piece of wood removed from the mosque during renovations in 1969-70. It was approximately 1500 to 1900 years old (LIPHSCHITZ et al., 1997). Three recent samples of megagametophyte tissue also were examined in this study. They were collected for comparison to the sequences from the ancient Taurus cedar specimens. They were from living $C$. libani trees sampled at two sites, Afyon-Sultandag (elevation: $1400 \mathrm{~m}$; latitude: $38^{\circ} 32^{\prime} 02^{\prime} \mathrm{N}$; longitude: $31^{\circ} 09^{\prime} 07^{\prime \prime} \mathrm{E}$; one specimen), and Isparta-Kapıdag (elevation: $1600 \mathrm{~m}$; latitude: $38^{\circ} 05^{\prime} 23^{\prime \prime} \mathrm{N}$; longitude: $30^{\circ} 42^{\prime} 20^{\prime \prime} \mathrm{E}$; two specimens), both located southwest of Gordion in Turkey, respectively). The specimens were designated as ZK AS 31704 4, ZK IK 31704 4, and ZK IK 3170412.

\section{DNA extraction protocol}

Prior to this study, the laboratory had never been used to examine Taurus cedar tissues or nucleic acids. All work surfaces were cleaned with Clorox (undiluted), followed by $95 \%$ ethanol. All tubes, containers, and solutions were autoclaved prior to use. Because wood is porous, it is impossible to sterilize the surfaces of the

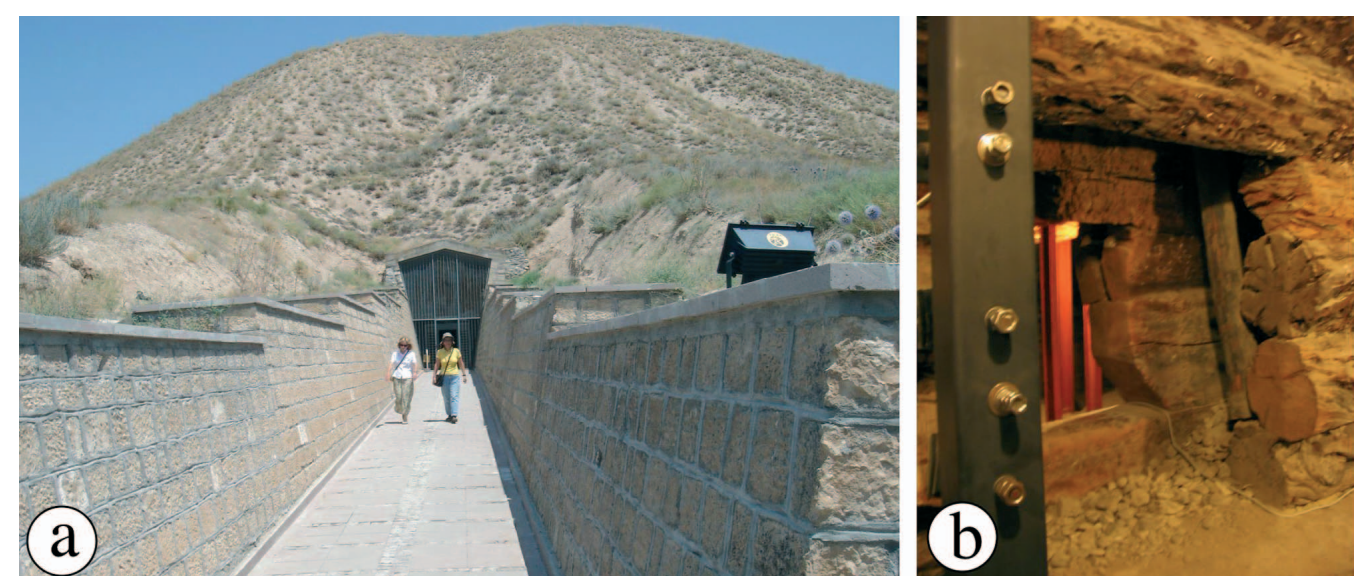

Figure 2. - Views of the Midas Tumulus. (a) Exterior of the Tumulus showing its large size, and relatively arid surface. (b) Interior of the central chamber of the Tumulus, with logs and timbers (juniper and pine) visible. The logs and timbers are in states of relatively good preservation. Cedar wood (the source of wood for this study) is found further inside this Tumulus. 
wood. Therefore, contaminants from fungi, humans, and other organisms were expected. To minimize the concentrations of contaminants, the exposed surfaces of the wood samples were removed with a sterile scalpel. Then, a new sterile scalpel blade was used to remove wood from the interior portion of the specimens. These interior samples were stored in sterilized microfuge tubes at $-80^{\circ} \mathrm{C}$ prior to extraction of the DNA. Extraction was accomplished using the CTAB (cetyltrimethylammonium bromide, or hexadecyltrimethylammonium bromide) method of Rogers and BENDICH (1985, 1988, 1994). The frozen pieces (ancient and modern, separately) were ground in a cold (stored at $-20^{\circ} \mathrm{C}$ ) sterile mortar and pestle. Then, the ground samples each were transferred into sterile microfuge tubes. For each $\mathrm{mg}$ of powdered wood, $2 \mu \mathrm{l}$ of $65^{\circ} \mathrm{C}$ extraction buffer $(2 \%$ CTAB, $100 \mathrm{mM}$ Tris ( $\mathrm{pH}$ 8.0), $20 \mathrm{mM}$ EDTA, $1.4 \mathrm{M} \mathrm{NaCl}$ and $2 \%$ polyvinylpyrrolidone (PVP)) was added and mixed thoroughly. First, the mixture was incubated at $65^{\circ} \mathrm{C}$ for 30 minutes. Then, the mixture was emulsified with an equal volume of chloroform/isoamyl alcohol (24:1) and centrifuged for 1 minute in a microfuge. The aqueous phase was transferred into a new microfuge tube, followed by addition of one-fifth volume of a $5 \%$ CTAB/0.7M NaCl solution. A second chloroform/isoamyl alcohol extraction was performed. Following 1 minute of centrifugation in a microfuge, the aqueous phase was transferred into a new microfuge tube and one volume isopropanol was added, followed by gentle mixing. Following at least 2 hours at $-4^{\circ} \mathrm{C}$, the precipitate was pelleted by centrifugation in a microfuge for 5 minutes. The pellet was washed once with cold isopropanol, followed by centrifugation ( 5 minutes). Then, the pellet was rehydrated in $50 \mu \mathrm{l}$ of high salt TE (10 mM Tris ( $\mathrm{pH} 8.0), 1$ $\mathrm{mM}$ EDTA, $1 \mathrm{M} \mathrm{NaCl}$ ) by heating at $65^{\circ} \mathrm{C}$ for $15 \mathrm{~min}-$ utes and occasional vortexing. Two volumes of cold $95 \%$ ethanol were added, followed by gentle mixing. The DNA was allowed to precipitate at $-20^{\circ} \mathrm{C}$ for at least 2 hours. Following centrifugation in a microfuge for at least 15 minutes, the pellet was washed with $80 \%$ ethanol. After centrifugation for 5 minutes, the ethanol was decanted off and the pellet was dried using a vacuum drier and was rehydrated in $20 \mu \mathrm{l} 0.1 \mathrm{X}$ TE buffer (1 mM Tris (pH 8.0), 0.1 mM EDTA). The extracted DNAs were subjected to electrophoresis at $5 \mathrm{~V} / \mathrm{cm}$ for 2 hours on $0.6 \%$ agarose gels (BioRad Laboratories, Hercules, CA), with TBE ( $89 \mathrm{mM}$ Tris, $89 \mathrm{mM}$ boric acid, $2 \mathrm{mM}$ EDTA) and $0.5 \mu \mathrm{g} / \mathrm{ml}$ ethidium bromide. Molecular weight markers (1kb ladder, Invitrogen, Inc., Frederick, MD) were used as size markers on each gel.

\section{Polymerase Chain Reaction (PCR) amplification / reamplification}

To characterize the extracted ancient DNA, primers for PCR were used that amplify all or parts of the ribosomal DNA (rDNA) internal transcribed spacers (ITS1 and ITS2) of conifers. To amplify the entire region from the 3' end of the rDNA small subunit gene through the 5' end of the rDNA large subunit gene (including ITS1, the 5.8S gene, and ITS2), primers prITS5 (GGAAGTAAAAGTCGTAACAAGG, forward primer) and prITS4 (TCCTCCGCTTATTGATATGC, reverse primer) (WHITE et al., 1990) were used. Based on the sequences from fresh megagametyphyte tissue of C. libani (KAYA, unpublished data), the total length of the amplified fragment generated using this primer pair is approximately $710-720 \mathrm{bp}$ in length. For the ITS1 region, primers ITSPlant1 (TCCGTATGTGAACCTGCGG, forward primer) and ITS-Gym2 (GGGGAATCCTGGTTAGTTC, reverse primer) were used. For $C$. libani, these generate an amplicon of approximately $350 \mathrm{bp}$ in length. For the ITS2 region, the primers, ITS-Gym3 (GCACCGATGAAGAATGTAGC, forward primer) and ITS-Plant4B (GGGGAATCCTGGTTAGTTTC, reverse primer) were utilized. This would generate an amplicon of approximately $430 \mathrm{bp}$ in length.

The initial PCR reaction mixtures consisted of 25 pmol of each primer (primer pairs prITS4/prITS5, ITSPlant1/ITS-Gym2, and ITSGym3/ITS-Plant4B, all were used in separate reactions), $10 \mathrm{mM}$ dNTP (equimolar amounts of each dNTP), $1.5 \mathrm{mM} \mathrm{MgCl}_{2}, 5$ units/ $\mu \mathrm{Taq}$ DNA polymerase (GeneAmp PCR Amplification Kit, Applied Biosystems, Foster, CA) and $1 \mu$ l of each DNA solution. Several different temperature programs were used in the PCR steps for this study using a programmable thermal cycler (Mastercycler, Eppendorf, New York, NY). For the initial amplifications, the following temperature regime was used: 5 minutes at $95^{\circ} \mathrm{C}$, then 50 cycles of 1 minute at $95^{\circ} \mathrm{C}, 2$ minutes at $45^{\circ} \mathrm{C}$, a ramp of $1^{\circ} \mathrm{C}$ per 8 seconds to $72^{\circ} \mathrm{C}$ and 2 minutes at $72^{\circ} \mathrm{C}$. This was followed by 10 minutes at $72^{\circ} \mathrm{C}$. The PCR amplified products then were stored at $-20^{\circ} \mathrm{C}$ until needed. A $5 \mu$ l aliquot of each PCR reaction was subjected to electrophoresis on an agarose gel (described above), except the gels were $1 \%$, and the running time was 2.5 hours.

After examination of the gel photograph, the amplified PCR products were used as templates for a second round of PCR amplification (termed the first round of reamplification), utilizing $2 \mu \mathrm{l}$ of the initial PCR reactions, and placed into new PCR reaction mixtures (as above). The first reamplification temperature regime was: 5 minutes at $95^{\circ} \mathrm{C}$, then 50 cycles of 1 minute at $95^{\circ} \mathrm{C}, 4$ minutes at $55^{\circ} \mathrm{C}$, a ramp of $1^{\circ} \mathrm{C}$ per 8 seconds to $72^{\circ} \mathrm{C}$ and 4 minutes at $72^{\circ} \mathrm{C}$. This was followed by 10 minutes at $72^{\circ} \mathrm{C}$. All three primer sets were used. After examination of the gel photograph, the amplified PCR products were used as templates for another set of PCR reamplification reactions, utilizing $2 \mu \mathrm{l}$ of the PCR reactions from the first set of reamplifications. The second round used four temperature regimes that varied in their annealing temperatures. The first was: 5 minutes at $95^{\circ} \mathrm{C}$, then 50 cycles of 1 minute at $95^{\circ} \mathrm{C}, 4$ minutes at $45^{\circ} \mathrm{C}$, a ramp of $1^{\circ} \mathrm{C}$ per 8 seconds to $72^{\circ} \mathrm{C}$ and 4 minutes at $72{ }^{\circ} \mathrm{C}$; followed by 10 minutes at $72^{\circ} \mathrm{C}$. The second, third, and fourth programs used 50,55 , and $57^{\circ} \mathrm{C}$ (respectively) as the annealing temperature, rather than $45^{\circ} \mathrm{C}$, but otherwise were the same as the first program. Only two of the primer pairs were used (ITS-Plant1/ITSGym2, and ITSGym3/ITS-Plant4B).

\section{DNA sequencing}

Single amplification bands from each successful amplification and reamplification reaction were purified and isolated on $1.5 \%$ low melting point agarose gels 
(NuSive GTG, FMC Bio Products, Rockland, ME, USA) using a freeze and centrifugation method (TAUTZ and RENZ, 1983) to separate the DNA from the agarose. The sequences from isolated amplified bands were determined employing the above primers using a Prism Ready Dye Deoxy Terminator Cycle Sequencing Kit (Applied Biosystems, Inc., Foster, CA) and an Automated DNA Sequencer (Applied Biosystems, Inc., Foster, CA; Model 310).

\section{BLAST searches and phylogenetic analyses}

Sequences were compared with nineteen conifer rDNA ITS sequences from NCBI (National Center for Biolotechnology Information) (Larix gmelinii - GenBank accession number AY523449, L. potaninii - AF538062, Metasequoia glyptstroboides - AF387530, Picea glauca AF136621, Pinus echinata - AF367378, Pinus krempfii AF305061, Pinus manticola - AY619694, Pinus massoniana - AF305063, Pinus palustris - AF305362, Pinus taeda - AF367379, Pinus techunumanii - AF200524, Pseudotsuga menziesii - AF041353, Sequoia sempervirens - AF387521, Taxus brevifolia = AF259295, Thuja occidentalis = AY846284 and Tsuga mertensiana AY570231). Additionally, we determined the rDNA ITS sequences from three Taurus cedar trees, using megagametophyte tissue. BLAST searches of international sequence databases (using Baylor College of Medicine internet site, gapped BLASTN search, http://searchlauncher.bcm.tmc.edu/seq-search/nucleic_acidsearch.html; and the NCBI site, BLASTN search, http://www.ncbi.nlm.nih.gov/) were used to determine the most closely related species to each sequence. Sequences from ancient Taurus cedar wood, Taurus cedar megagametophytes (fresh tissues), and selected the sequences (above) were aligned using ClustalW 1.8, using the Baylor College of Medicine internet site (http://searchlauncher.bcm.tmc.edu/multi-align/multialign.html). Phylogenetic analyses were conducted using PAUP (Phylogenetic Analysis using Parsimony, Version 4.0b; SwOFFORD, 2000). The phylogram was generated using maximum parsimony, heuristic search option, with gaps scored as a fifth base. Maximum parsimony analysis was also performed on the same data set scoring the gaps as missing data.

Table 1. - Results from PCR amplification attempts, amplification totals, and sequencing results. In all cases the results are shown with two numbers separated by a slash. The number on the right indicates the total number of attempts (PCR, sequencing, or BLAST searches), while the number on the left indicates the number of successes for each. N/A indicates no attempts.

\begin{tabular}{|c|c|c|c|c|c|c|}
\hline \multirow{3}{*}{ PCR and sequencing ${ }^{a}$} & \multicolumn{3}{|r|}{ PRIMER } & \multicolumn{2}{|l|}{ PAIRS $^{b}$} & \multirow{3}{*}{$\begin{array}{c}3 / 4 \\
\text { Gordion }\end{array}$} \\
\hline & $4 / 5$ & $4 / 5$ & $1 / 2$ & $1 / 2$ & $3 / 4$ & \\
\hline & Al-Aqsa & Gordion & Al-Aqsa & Gordion & Al-Aqsa & \\
\hline Initial amplification & $0 / 10$ & $0 / 12$ & $2 / 12$ & $2 / 18$ & $0 / 12$ & $2 / 18$ \\
\hline Reamplification 1 (55) & $0 / 3$ & $0 / 3$ & $0 / 6$ & $0 / 6$ & $3 / 6$ & $0 / 6$ \\
\hline Reamplification 2.1 (45) & N/A & $N / A$ & $0 / 3$ & $0 / 3$ & $0 / 3$ & $0 / 3$ \\
\hline Reamplification 2.2 (50) & N/A & N/A & $0 / 3$ & $0 / 3$ & $0 / 3$ & $0 / 3$ \\
\hline Reamplification $2.3(55,57)^{\mathrm{C}}$ & N/A & N/A & $4 / 9$ & $1 / 9$ & $5 / 9$ & $3 / 9$ \\
\hline Amplification totals & $0 / 13$ & $1 / 12$ & $6 / 33$ & $3 / 39$ & $8 / 33$ & $5 / 39$ \\
\hline Sequencing ${ }^{d}$ & $\mathrm{~N} / \mathrm{A}$ & $N / A$ & $16 / 16$ & $9 / 14$ & $18 / 18$ & $13 / 18$ \\
\hline Possible gymnosperm ${ }^{e}$ & N/A & N/A & $0 / 16$ & $1 / 9$ & $1 / 18$ & $0 / 13$ \\
\hline
\end{tabular}

${ }^{a}$ For the initial amplifications, $1 \mu \mathrm{l}$ of each DNA solution was used in $25 \mu \mathrm{l}$ PCR reaction mixtures. For each of the reamplification attempts, $2 \mu \mathrm{l}$ of the previous amplification reactions were used in subsequent $25 \mu \mathrm{l}$ PCR reaction mixtures. Annealing temperatures are noted in parentheses.

${ }^{\text {b }}$ Primer pair $4 / 5$ is prITS4 and prITS5, pair $1 / 2$ is ITS-Plant1 and ITS-Gym2, and pair 3/4 is ITSGym3 and ITS-Plant4B. Results indicate the number of reactions that generated bands visualized on agarose gels (successes/attempts).

c The annealing temperature for the $3 / 4$ pair was $55^{\circ} \mathrm{C}$, and that for the $1 / 2$ pair was $57^{\circ} \mathrm{C}$.

${ }^{d}$ PCR amplification bands were eluted from low melting point agarose gels (as described in the Materials and Methods). In several cases, more than one band was evident. In these cases, each band was eluted separately. Each of the eluted DNAs was subjected to PCR cycle sequencing and analysis on an ABI 310 automated DNA sequencer. The number of readable sequences over the total number of sequencing reactions analyzed in the automated DNA sequencer is indicated.

e The number of sequences that were most similar to ITS rDNA sequences from gymnosperms is indicated compared to the total number of sequences in BLASTN searches. The other sequences were closest to the following organism sequences at NCBI: Gordion samples - ten were closest to human sequences, one was closest to fungal sequences, and ten had no significant similarity with any other sequence; Al-Aksa samples - twelve were closest to human sequences, nine were closest to fungal sequences, one was closest to an algal sequence, and eleven had no significant similarity with any other sequence. 


\section{Results}

The wood from the Gordion site was noticeably softer than the sample from the Al-Aksa Mosque, and thus grinding was much easier with the Gordion wood. This probably is due to extensive degradation of the wood by soft-rot fungi, described elsewhere (FILLEY et al., 2001). Although signs of wood degradation were evident, of the one-hundred sixty-nine attempts to amplify the rDNA regions (Table 1), twenty-three (or $13.6 \%$ ) yielded visible bands on agarose gels (some yielded multiple bands). From these, fifty-six readable DNA sequences were obtained, twenty-two from the Gordion wood sample, and thirty-four from the Al-Aksa wood sample. For the sequences from the Gordion sample, in BLAST searches, only one was closest to gymnosperm rDNA ITS sequences. The others were closest to human sequences (ten total), fungi (one), or were not similar to any other sequences (ten). For the sequences from the Al-Aksa sample, only one was closest to gymnosperm rDNA ITS sequences. The others were closest to human (twelve), fungi (nine), algae (one), or were not similar to any other sequences (eleven).

The total length of accurately readable sequence determined for the one Gordion wood sample was 181 nucleotides, and included the extreme 5 ' end of the $5.8 \mathrm{~S}$ gene, and about half of the 3' end of ITS1. The total length of accurately readable sequence from the one $\mathrm{Al}$ Aksa wood sample was 265 nucleotides, and was composed of much of the 5.8S gene and part of the 5' end of ITS2. These sequences were aligned with analogous sequences from several species in the Coniferales (as indicated in the Materials and Methods). Phylogenetic analyses were performed using 479 nucleotide positions, which included the 3 ' half of ITS1, the entire 5.8S gene, and the 5' half of ITS2. Phylogenetic analyses with or without gaps considered as a fifth base yielded similar results (Figure 3). The branches with the two sequences from ancient wood were always in the same position,

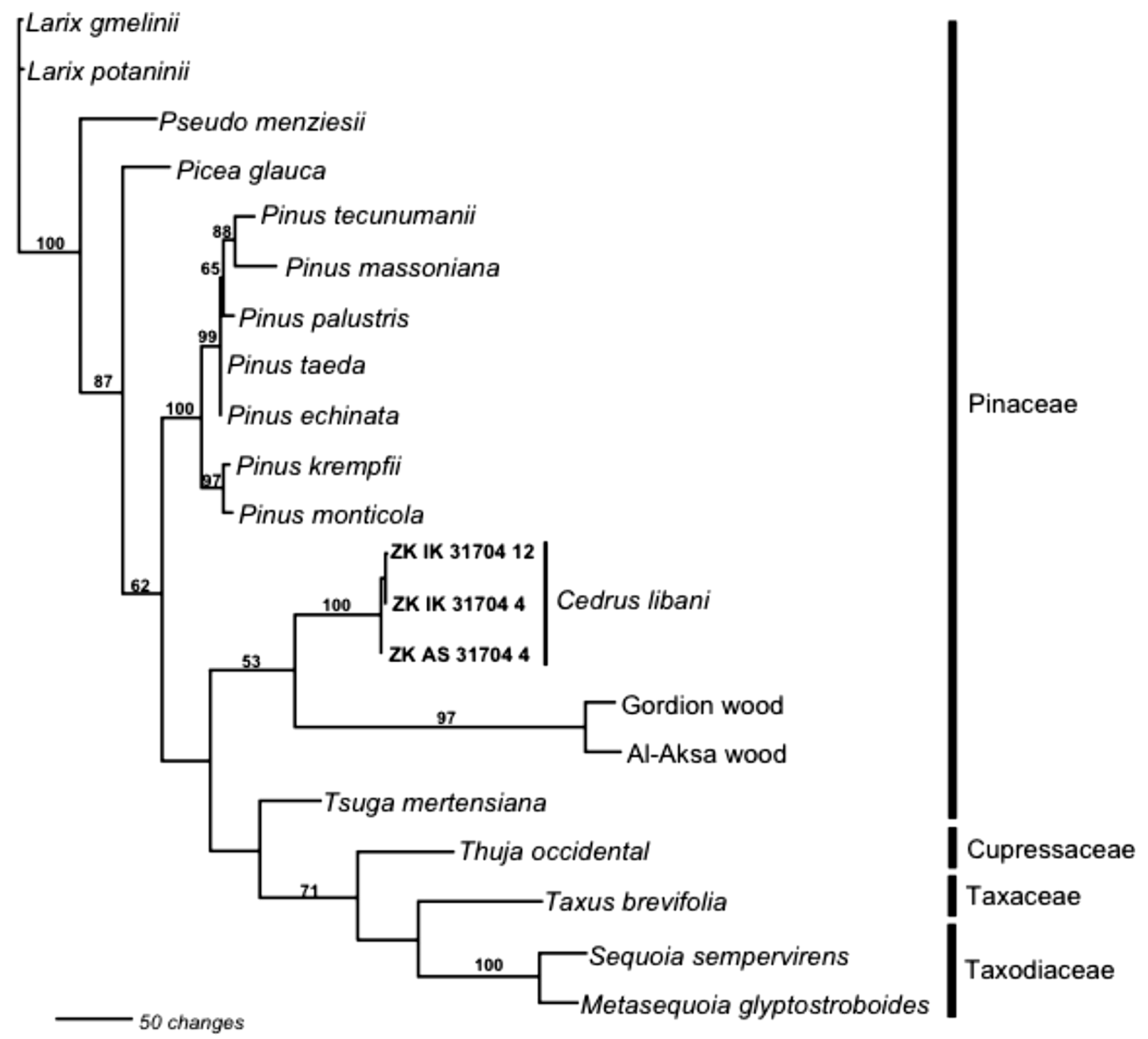

Figure 3. - Maximum parsimony tree based on sequences of rDNA ITS regions from selected conifers, including DNA from modern C. libani (ZK AS 31704 4, ZK IK 31704 4, and ZK IK 31704 12) and from the Gordion and Al-Aksa cedar wood specimens. The tree presented is one of nine most parsimonious trees (1158 steps, $\mathrm{CI}=0.6796, \mathrm{HI}=0.3204, \mathrm{RI}=0.6577, \mathrm{RC}=0.4470$ ). All nine trees are invariant with respect to the placement of the two sequences from the ancient wood. The analyses were based on comparison 479 nucleotide positions for each of the 21 taxa in the data matrix. The Gordion ancient wood sequence consisted of 181 nucleotides (plus 26 gap positions). The Al-Aksa ancient wood sequence consisted of 265 nucleotides (plus 75 gap positions). Gaps were included as a fifth base in the analysis that produced this tree. Analysis that considered gaps as missing data resulted in seven most parsimonious trees $(791$ steps, CI $=0.6991$, HI $=0.3009$, $\mathrm{RI}=0.6801, \mathrm{RC}=0.4755)$. The placement of the Gordion and Al-Aksa sequences was exactly the same for all sixteen trees. 
nearest to the clade with the recent $C$. libani rDNA ITS sequences. Maximum parsimony analyses with gaps counted as a fifth base resulted in nine most parsimonious trees, with length of 1158 , consistency index $(\mathrm{CI})=$ 0.6796 , homoplasy index $(\mathrm{HI})=0.3204$, retention index $(\mathrm{RI})=0.6577$, and rescaled retention index $(\mathrm{RC})=$ 0.4470. Bootstrap analyses indicated that the C. libani branch had $100 \%$ support and the branch with the two ancient specimens had $97 \%$ support. When gaps were considered as missing data, seven most parsimonious trees resulted, with length of $781, \mathrm{CI}=0.6991, \mathrm{HI}=$ $0.3009, \mathrm{RI}=0.6801$, and $\mathrm{RC}=0.4755$. Support for the two branches was $100 \%$ and $69 \%$, respectively.

While the two sequences appear to be authentic Taurus cedar sequences, the phylogenetic analysis (Figure 3 ) placed them distant from the Taurus cedar sequences derived from currently growing plants in Afyon-Sultandag and Isparta-Kapıdag (Figure 1). The sequence data from both samples indicated that the DNA templates in the ancient Taurus cedar wood were damaged, as evidenced by the low yield of sequences, and within the readable sequences there were regions where nucleotide determinations were difficult because the signals were weak.

\section{Discussion}

The results of the present study indicate that the characterization of DNA from cedar wood as old as 2700 years old is possible. Further studies on this and other ancient wood specimens may help to answer some of the questions such as how the past distribution of the species compares with the present. Such studies could be useful in elucidating the origins of ancient wood specimens in these and other archaeological sites. Furthermore, the alleles that may have been lost in the past might be recoverable, although degradation will limit such recovery efforts. The potential of wood for molecular genetic investigations was explored by DEGUILLOUX et al. (2002) and it was concluded that younger tissues from the outer part of the trunk were more likely to yield DNA for PCR amplification than were samples from older wood from the heartwood. Furthermore, there was a better chance of obtaining longer amplified DNA fragments compared with the older samples. For most wood samples, the extracted DNA was degraded. Genomic regions that gave the best results were those of small size and present in high copy number, such as chloroplast, mitochondrial, or repeated nuclear sequences (GUGERLI et al., 2005). Nevertheless, TANI et al. (2003) studied nucleotide diversity of several nuclear genes which was estimated from DNA amplified from fossil heartwood of six trees of Japanese cedar (Cryptomeria japonica), buried for about 3600 years by comparing DNA sequences of nearby living trees. The previous aDNA studies from fossils and arcahealogical remains of wood agree that authenticity of aDNA and its degradation are the major concerns (http:// 193.51.111.211/fossilva/index.htm; GuGERLI et al., 2005; TANI et al., 2003; DEguILLOUX et al., 2002).

The extent of contamination and degradation were expected in this study. We and others have noted and documented molecular damage and contamination in ancient specimens (GuGERLI et al., 2005; PÄÄBO et al., 2004; RoGers et al., 1985, 1989, 2004, 2005; WAYNE et al., 1999). The Gordion site and the Al-Aksa Mosque are frequented by human visitors. Additionally, the samples were all handled by an unknown number of people. Thus, it is not surprising that most sequences obtained were of human origin. In the future, researchers excavating sites of antiquity might perform some of the sampling using sterile methods to collect and store the specimens. This probably would not reduce all forms of contamination, but should reduce the amount of human DNA contamination. Contamination from fungi also is of major concern. Fungi are ubiquitous and readily travel in the air, soil, and water. Thus, fungal contamination at these sites is expected.

In this study, we saw evidence of degradation in two ways. First, the Gordion wood sample was soft, indicating the action of fungi (or analogous processes). Second, the DNA from each of the wood specimens was evident from the low frequency of PCR amplification and the weak DNA sequences. Degradation of the DNA in the wood samples probably originated from at least three sources. First, as wood matures, the amount of DNA and RNA in the cells is reduced as these nucleic acids are degraded in the natural maturation processes. Cambial cells would be expected to retain more of a full complement of DNA and RNA sequences, which has been indicated in other wood studies (DEGUILloux et al., 2002). Since our samples consisted of mature wood without cambium, part of the degradation might have originated from the wood maturation process.

Second, the more rapidly the tissues dry, the less DNA degradation will occur (Rogers et al., 1989). Primarily, this is because enzymes and other degradative processes require hydration of the nucleic acids (LINDAHL, 1993, 1997; Rogers et al., 1989; 2004, 2005). Therefore, if the wood dried rapidly and remained dehydrated, the nucleic acids would have a higher probability of remaining undamaged. Wood in the Midas Tumulus is buried under tens of meters of soil. Although the site is semiarid, some rain water probably has seeped through the soil from above. Additionally, the interior of the Tumulus can be much cooler in the summer than outside. Thus, it is possible that moisture from the air condenses inside the Tumulus during warmer months. At Al-Aksa, it appears that the preservation is somewhat better, since this wood remained relatively hard. The constant supply of dry air through the building, and protection from precipitation may have helped to preserve this wood.

Third, the cedar wood in the Midas Tumulus previously was examined microscopically (FILLEY et al., 2001) and was infected with soft-rot fungi. The fungi had degraded the wood to a significant degree. The degradation of the wood structure indicates that the probability of nucleic acid degradation is higher than it would be otherwise. Also, the presence of a large population of fungi indicates that the wood was likely hydrated, at least to an extent. The presence of water would increase degradation via biotic as well as abiotic mechanisms. As stated above, the Gordion wood samples were soft compared to the Al-Aksa samples, which is consistent with 
degradation by fungi. The hardness of the Al-Aksa sample is encouraging, since it indicates that this wood may have less degradation both from fungi and the results of hydration.

The large distances between the three Taurus cedar sequences from fresh tissues and the ancient Gordion and Al-Aksa Taurus cedar wood sequences seen in the phylogram may be caused by one of several possibilities. First, the DNA within the samples could be significantly degraded. This is likely, since the amplification and sequencing were difficult and inconsistent. Second, the sequences could be from contaminants, such as from species close to Taurus cedar. Other varieties of $C$. libani exist in the Middle East, and it is possible (although unlikely) that pollen or other contaminating cells became embedded in the wood samples. Third, the wood might be from an extinct different species of Cedrus. Since no preserved wood or fossil evidence exists for this possibility, it is unlikely that this is the case. Fourth, the genetic diversity of Taurus cedar has decreased during the past 2700 years. Long ago, the natural distribution of Taurus cedar may have been continuous from Afyon-Sultandag to the Gordion site, but these natural Taurus cedar forests were lost due to the many years of human activities. Similarly, the forests were continuous through other parts of the Middle East, including Israel. Again, anthropogenic deforestation has severely limited the extent of the $C$. libani forests. It is likely that the genetic diversity of the species concurrently has been reduced. Since the sequence distances are large in the phylogenetic analyses between the ancient wood samples and the recent $C$. libani specimens, it is likely that more than one of the above possibilities is responsible for the sequence variation.

These results indicate that the wood can be utilized in aDNA studies, but that degradation is likely, and the specimens may be heavily contaminated through human contact and microbial colonization (GUGERLI et al., 2005). For future aDNA studies of archaeological wood specimens, sample collection and preparation should be carried out in aseptic conditions in order to avoid further contamination. Dozens of DNA extractions and 169 PCR amplification reactions were attempted, from which 56 sequences were obtained. Only two of the resulting sequences were consistent with being from cedar. However, since the samples are destroyed in the process, we were restricted from sampling the wood from many of the more suitable portions of the cedar logs at the Gordion site. For future aDNA studies using wood, samples taken from the areas close to bark, knots or wounded areas would be more useful since these areas are the most likely places that some intact parenchyma cells (containing cytoplasm and nuclei) could be found included among the xylem tissues during wood formation. Additionally, the potential for contamination would be reduced if specimens that are distant from areas of high visitor traffic could be assayed. If we had flexibility in sampling from the ancient cedar logs in the Tumulus of King Midas in the Gordion site (Figure 2 ), the DNA amplification would be more likely to yield DNA sequences from the cedar wood rather than from contaminating organisms.

\section{Acknowledgements}

We express our gratitude to the Fulbright Scholar Program for providing Prof. Z. KAYA a research grant at SUNY ESF (Fulbright Research Grant \# 24612) that made possible our collaboration on genetic characterization of ancient Taurus cedar wood samples from Gordion. We are also grateful to the Anatolian Civilization Museum Authorities (Assistant Director Híkmet DenizLi and Archaeologist MEHMET AKALIN) for providing us the Gordion cedar wood samples, and to Professor S. LEV-YADUN of Haifa University, Israel for providing the Al-Aksa mosque cedar wood specimens. We thank GANG ZHANG, SeunG-Geuk Shin, and Vincent Theraisnathan for their help in preparation of parts of the manuscript.

\section{References}

Aytug, B. (1988): Le mobilier funeraire du roi Midas I. Pact 22: 357-368.

BOYDAK, M. (2003): Regeneration of Lebanon cedar (Cedrus libani A. Rich.) on karstic lands in Turkey. Forest Ecol. Manag. 178: 231-243.

CANO, R. J. and M. K. BorUCKI (1995): Revival and identification of bacterial spores in 25- and 40-million-yearold Dominican amber. Science 268: 1060-1064.

Deguilloux, M.-F., M.-H. Pemong and R. J. Petit (2002): Novel perspectives in wood certification and forensics: dry wood as a source of DNA. Proc. Royal Soc. Lond. Ser. B 269: 1039-1046.

Deguilloux, M.-F., M.-H. Pemonge and R. J. Petit (2004): DNA-based control of oak wood geographic origin in the context of the cooperage industry. Annals Forest Sci. 61: 97-104.

Degullloux, M.-F., M.-H. Pemonge, L. Bertel, A. Kremer and R. J. PEтit (2003): Checking the geographical origin of oak wood: molecular and statistical tools. Molec. Ecol. 12: $1629-1636$.

Dumolin-Lapègue, S., M.-H. Pemonge, L. Gielly, P. TABERLET and R. J. Petit (1999): Amplification of oak DNA from ancient and modern wood. Molec. Ecol. 8: 2137-2140.

Filley, T. R., R. A. Blanchette, E. Simpson and M. L. FOGEL (2001): Nitrogen cycling by wood decomposing soft-rot fungi in the "King Midas tomb," Gordion, Turkey. Proc. Natl. Acad. Sci USA 98: 13346-13350.

Gugerli, F., F. Parducci, L. and R. J. Petit (2005): Ancient plant DNA: review and prospects. New Phytol. 166: 409-418.

Hofreiter, M., D. Serre, H. N. Poinar, M. Kuch and S. РёÄво (2001): Ancient DNA. Nature Rev. Genet. 2: 353-359.

IÇGEN, Y. (2002): Genetic composition of Pinus brutia Ten. forests established with seeds from seed stands and orchards determined by using DNA markers. Ph.D. Dissertation, Middle East Technical University, Department of Biological Sciences, Ankara, Turkey.

KandedmiR, G., I. KandemiR and Z. Kaya (2004): The Pattern of Genetic Variation in Turkish red pine (Pinus brutia Ten.) seed stands as determined by RAPD markers. Silvae Genetica 53: 169-175.

KAYA, Z. and D. B. NEALE (1995): Linkage map based on randomly amplified polymorphic DNA (RAPD) markers in Pinus brutia Ten. Silvae Genetica 44: 110-116.

KAYIHAN, G. (2000): The genetic structure of Cedrus libani populations determined by DNA markers. MS Thesis, Middle East Technical University, Department of Biology, Ankara, Turkey.

KIM, S., D. E. Soltis, P. S. Soltis and Y. SuH (2004): DNA sequences from Miocene fossils: an $\mathrm{ndhF}$ sequence of 
Magnolia latahensis (Magnoliaceae) and an rbcL sequence of Persea pseudocarolinensis (Lauraceae). Amer. J. Bot. 91: 615-620.

LINDAHL, T. (1993): Instability and decay of the primary structure of DNA. Nature 362: 709-715.

LINDAHL, T. (1997): Facts and artifacts of ancient DNA. Cell 90: $1-3$.

Lipschitz, N., G. Biger, G. Bonani and W. Woolphi (1997): Comparative dating methods: Botanical identification and ${ }^{14} \mathrm{C}$ dating of carved panels and beams from the Al-Aksa Mosque in Jerusalem. J. Archaeolog. Sci. 24: 1045-1050.

Ma, L. J., S. O. Rogers, C. Catranis and W. T. Starmer (2000): Detection and characterization of ancient fungi entrapped in glacial ice. Mycologia 92: 286-295.

MILLER, N. F. (1999): Interpreting ancient environment and patterns of land use: Seeds, charcoal and archaeological context. TUBA-AR II: 15-29.

MilleR, N. F. (1998): The macrobotanical evidence for vegetation in the Near East, c 18000/16000 BC to 4000 BC. Plaeorient. 23/2: 197-207.

PÄÄ̈o, S., H. Poinar, D. Serre, V. Jaenicke-Despres, J. Hebler, N. Rohland, M. Kuch, J. Krause, L. VigiLANT and M. Hofreiter (2004): Genetic analyses from ancient DNA. Ann. Rev. Genet. 38: 645-679.

PÄÄBO, S. (1993): Ancient DNA. Sci. Amer. 267: 60-66.

PÄÄво, S. (1988): Molecular clonning of Ancient Egyptian Mummy DNA. Nature 314: 644-645.

PARDUCCI, L. and R. J. PetiT (2004): Ancient DNA unlocking plants' fossil secrets. New Phytol. 161: 335-339.

Rogers, S. O. (1994): Phylogenetic and taxonomic information from herbarium and mummified DNA, pp. 47-67 in DNA Utilization, Intellectual Property and Fossil DNA, edited by R. P. AdAms, J. Miller, E. GolenberG, and J. E. AdAms, Missouri Botanical Gardens Press, St. Louis/MO.

Rogers, S. O. and A. J. BENDICH (1985): Extraction of DNA from milligram amounts of fresh, herbarium and mummified plant tissues. Plant Mol. Biol. 5: 69-76.

Rogers, S. O. and A. J. BENDICH (1988): Extraction of DNA from plant tissues, pp. A6:1-10. In: Plant Molecular Biology Manual, edited by S. B. GeLvin and
R. A. SchilPeroort, Kluwer Academic Publishers, Boston/MA

Rogers, S. O. and A. J. BENDICH (1994): Extraction of total cellular DNA from plants, algae, and fungi, pp. D1:1-8. In: Plant Molecular Biology Manual, $2^{\text {nd }}$ ed., edited by S. B. Gelvin and R. A. SchilPeroort, Kluwer Academic Publishers, Dordrecht, The Netherlands.

Rogers, S. O., L. MA, Y. ZhaO, C. M. CAtranis, W. T. Starmer and J. D. CASTEllo (2005): Recommendations for elimination of contaminants and authentication of isolates from ancient ice cores, pp. 5-21. In: Life in Ancient Ice, edited by J. D. CASTELlO and S. O. Rogers, Princeton University Press, Princeton/NJ.

Rogers, S. O., S. Rehner, C. Bledsoe, G. J. Mueller and J. F. AMmiRATi (1989): Extraction of DNA from Basidiomycetes for ribosomal DNA hybridizations. Can. J. Bot. 67: 1235-1243.

Rogers, S. O., V. Theraisnathan, L. J. Ma, Y. Zhao, G. Zhang, S. G. Shin, J. D. Castello and W. T. Starmer (2004): Comparison of protocols to decontaminate environmental ice samples for biological and molecular examinations. Appl. Environ. Microbiol. 70: 2540-2544.

Savolainen, V., P. CuÉnoud, R. Spichiger, M. D. P. MarTINEZ, M. CRÈvecoeur and J.-F. MANEN (1995): The use of herbarium specimens in DNA phylogenetics - evaluation and improvement. Plant Syst. Evol. 197: 87-98.

Suyama, T., K. Kawamuro, I. Kinoshita, K. Yoshimura, Y. Tsumura and H. TAKAHARA (1996): DNA sequence from a fossil pollen of Abies spp. from Pleistocene peat, in http://www.madsci.org/ (University of Washington, Medical School): The MadScientist Network.

SwOFFord, D. L. (2000): PAUP: Phylogenetic Analysis Using Parsimony, Version 4.03, Sinauer Associates, Sunderland/MA.

TANi, N., Y. Tsumura and H. Sato (2003): Nuclear gene sequences and DNA variation of Cryptomeria japonica samples from the postglacial period. Molec. Ecol. 12: 859-868.

TAUTZ, D. and M. RenZ (1983): An optimized freezesqueeze method for recovery of DNA from agarose gels. Anal. Biochem. 132: 14-19.

WAYNe, R. K., J. A. LEONARD and A. CoOPER (1999): Full of sound and fury: The recent history of ancient DNA. Ann. Rev. Ecol. Syst. 30: 457-477.

\title{
Stepwise Penalty Index Selection from Populations with a Hierarchical Structure
}

\author{
By R.-P. WeI $\left.{ }^{1)}{ }^{*}\right)$ and D. LINDGREN ${ }^{2)}$
}

(Received $5^{\text {th }}$ August 2005)

\footnotetext{
1) South China Agricultural University, Wushan, Guangzhou 510642, China, and Sino-Forest Corporation, 3815-29, 38/F., Sun Hung Kai Centre, 30 Harbour Road, Wanchai, Hong Kong.

$\left.{ }^{2}\right)$ Department of Forest Genetics and Plant Physiology, Swedish University of Agricultural Sciences, S-901 83 Umeå, Sweden.

*) Correspondence author and address: Run-Peng WeI, SinoForest Corporation, 3815-29, 38/F., Sun Hung Kai Centre, 30 Harbour Road, Wanchai, Hong Kong. Tel.: +852-2514 2124 . Fax +852-2877 0062. Email: runpeng-wei@sinoforest.com
}

\begin{abstract}
By adding a penalty to a candidate's breeding value for its relationship with the selected individuals, two indexes were constructed as criteria for stepwise selection of superior individuals from populations with a hierarchical structure. The relationship was expressed in terms of either family contribution or group coancestry. One of the indexes was derived from an optimal
\end{abstract}

